\title{
FISH COMMUNITY STRUCTURE IN RELATION TO WATER QUALITY OF THE DOWN STREAM OF MUSI RIVER, SOUTH SUMATERA, INDONESIA
}

\author{
Husnah"1), Eko Prianto ${ }^{1)}$, Makri"1), and Hilda Z. Dahlan ${ }^{21}$ \\ Researcher at the Research Institute for Open Water Fisheries, and Faculty of the Fisheries Faculty, Univ. PGRI Palembang \\ 2) The Faculty of Math and Natural Science, Sriwijaya University, Palembang \\ Received June 13-2008; Received in revised form July 25-2008; Accepted Nopember 24-2008
}

\begin{abstract}
Musi River is a large river with its drainage area covers three provinces, South Sumatera, Lampung, and Bengkulu, and with multi uses of its resources. At the down stream of Musi River, most activities are dominated by industries with their waste products go into the river which could harm its aquatic organism. Several assessment studies have been conducted in the Musi River, however they focused on physical and chemical aspects of the water. Aquatic organisms can reveal the real world effects of exceedences and consequent harm more precisely than can be predicted or measured on a chemical and or toxicity basis alone. Compared to other aquatic biota, fish are of particular interest for biological indicators. Species diversity and dominance are component of community structure that can be used to study several changes caused by the aquatic environment degradation The community structure of fish is frequently monitored to describe river conditions. Study in order to determine the fish community structure in relation to water quality of down stream of Musi River was conducted on April and June 2007. Sampling on physical and chemical parameters of the water and sediment, and fish sample were carried in each sampling site. Water sample was collected at a depth of $1.0 \mathrm{~m}$ from the water surface by using kemmerer water sampler. Some water quality parameters such as temperature, $\mathrm{pH}$, and dissolved oxygen were directly analyzed in the field, while other water quality parameters such as total suspended solids, total dissolved solids, biochemical oxygen demand, nitrate, and phosphate were analyzed in laboratory. Fish sample was collected from the experiment fishing and from the fishermen. Two type of fishing gears, electrofishing, and gill net with 8 different mesh sizes were used. Fish sample from fishing experiment and from the fishermen were collected, sorted based on the species, labelled, measured for their weight and individual number, and then preserved with $10 \%$ off formaldehyde water quality parameters were analyzed using principle component analysis while fish relative abundances were analyzed with cluster. Fish community structure through simple diversity and dominance index, and proportionate abundance of species (relative abundance) were correlated with the quality of aquatic environment. The down stream of Musi River station starting from Gandus to PT. SAP station was in degradation prosses state indicated by diversity index in the range of 1 to 2 and high proportion of small fish than that the large fish.
\end{abstract}

\section{KEYWORDS: fish community structure, diversity, dominance, water quality, Musi River}

\section{INTRODUCTION}

Musi River is a large river with its drainage area covers three provinces, South Sumatera, Lampung, and Bengkulu, and with multi uses of its resources. At the down stream of Musi River, around the Palembang city, most activities are dominated by industries with their waste product go into Musi River which could harm its aquatic organism. Several monitoring and assessment studies have been conducted in Musi River (Badan Pengendalian Dampak Lingkungan, 1997) however they mostly focused on physical dan chemical aspects of the water, but biological aspects.

Unlike chemical water quality, the aquatic biota does not respond instantaneously to normal short term events, unless they are catastrophic in nature. This implies that one variable used in chemical criteria application cannot make or break the aquatic biota its own. The biota can reveal the real world effects of exceedences and consequent harm more precisely than can be predicted or measured on a chemical and or toxicity basis alone (Simon, 1998). There some aquatic biota used as indicators of aquatic environment degradation such as plankton, benthic organisms, and fish (DeYoe, 2001; Zivic et al., 2004; Ganasan \& Hughes, 1998; Le land \& Fend, 1998; Soto-Galera et al., 1998).

Compared to other aquatic biota, fish are of particular interest for biological indicators since; a) they present in most water bodies; b) their taxonomy, ecological requirement, and life histories are generally better known than those of other assemblages; c) they occupy a variety of trophic levels and habitats; and d) they have both economic and aesthetic values and thus help raise awareness of the value of conserving aquatic systems (Hughes \& Oberdoff, 1998). The effect of environment degradation to freshwater fish can be approached from the population to the community level. Fish biotic integrity concept 
developed by Karr et al. (1986) in Smogor \& Angenmeier (1998), is based on the hypothesis that there are predictable relationship between fish assemblages structure and physical, chemical, and biological condition of stream systems (Hughes \& Oberdoff, 1998). This concept is widely used and adaptable specially for the countries having routine monitoring program and good data base record since the components to set up the index of fish integrity biotic index derived from spatial and time series data which are very seldom found in developing or some develop countries.

Species diversity and dominance are component of community structure that can be used to study several changes caused by the aquatic environment degradation (Odum after Newman, 1994). The community structure of fish is frequently monitored to describe river conditions (Schiemer, 2000). In addition, Ganasan \& Hughes (1998) mentioned that the presence, absence, and proportionate abunciance of species within fish assemblages indicate the quality of the physical, chemical, and biological condition in which they live.

The objective of this study was to determine the community structure of fish in relation to water quality of the down stream of Musi River, South Sumatera Indonesia.

\section{MATERIALS AND METHODS}

Field survey was conducted at the down stream of Musi River, South Sumatera Province of Indonesia on April and June 2007. Seventeen sampling stations were set up based on the characteristic of microhabitat such as the condition of riparian vegetation, the tributary and industrial area (Figure 1).

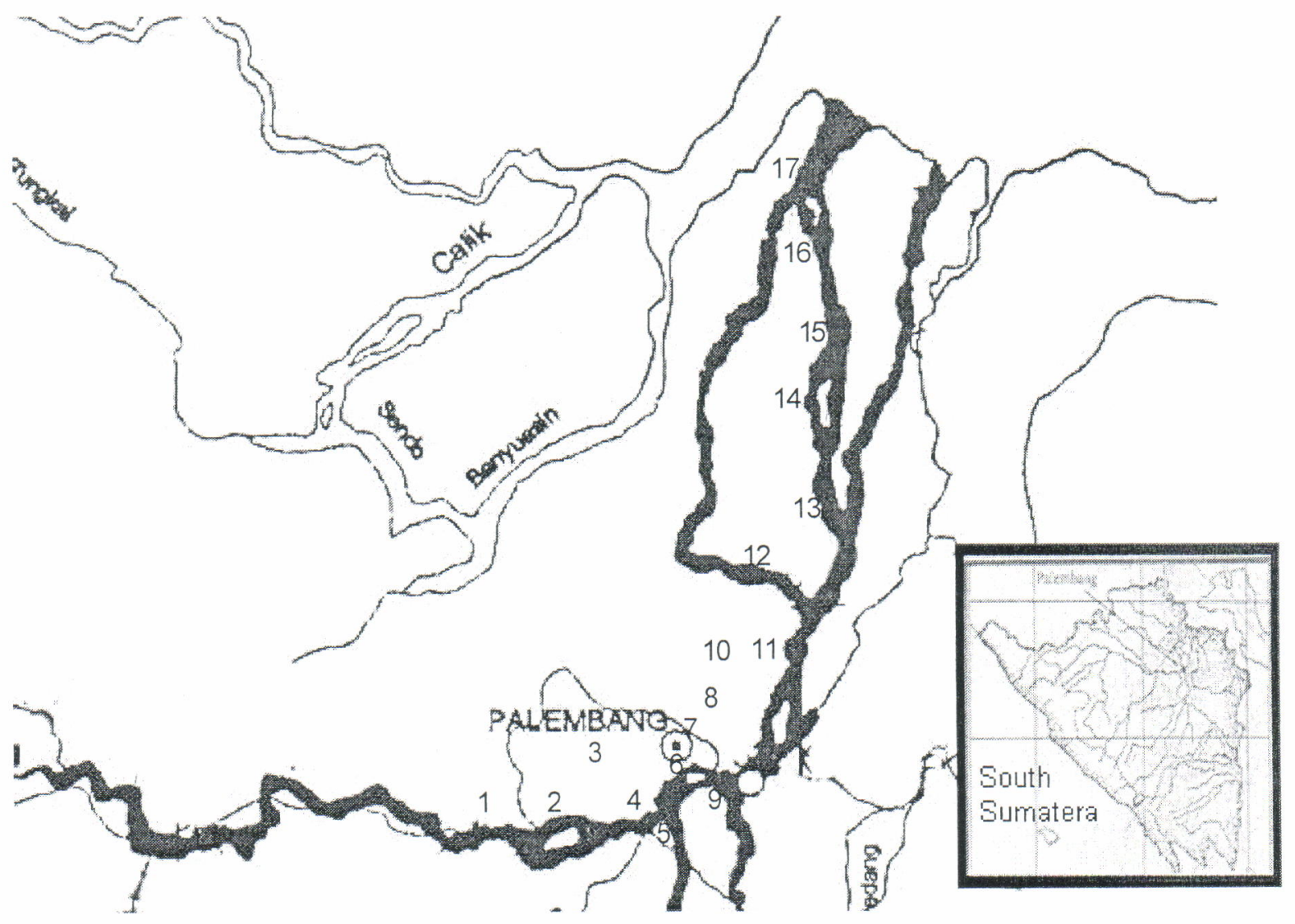

Figure 1. Sampling station for physical and chemical water quality parameters and fish sample at the down stream of Musi River, South Sumatera, Indonesia.

Remarks: 1. Pulokerto; 2. Gandus; 3. Musi II; 4. Muara Kramasan; 5. Muara Ogan; 6. Ampera; 7. Wilmar; 8. Pusri; 9. Hoktong; 10. Kundur River; 11. PT. SAP; 12. total suspended solids; 13. Upang; 14. Pre Cemara; 15. Cemara; 16. Pulau Payung; 17. Teluk Buyut 


\section{Water Quality Sampling}

Water sample with volume of $3 \mathrm{~L}$ were collected at $1 \mathrm{~m}$ depth from the water surface at each of the sampling sites by using Kemmerer water sampler. The water sample was distributed into three of 500 $\mathrm{mL}$ plastic bottle and one dissolved oxygen and biochemical oxygen demand bottle. Two bottle of 500
$\mathrm{mL}$ plastic bottle was preserved at temperature of $4^{\circ} \mathrm{C}$ for laboratory measurement. Parameters measured in the field were temperature, conductivity, $\mathrm{pH}$, salinity, total alkalinity, and total hardness, while in the laboratory, they were total suspended solids, total dissolved solids, organic carbon, phosphate, nitrate, nitrite, and ammonia (Table 1).

Table 1. Method used for measuring some water quality parameters

\begin{tabular}{ll}
\hline \multicolumn{1}{c}{ Water quality parameters } & \multicolumn{1}{c}{ Method of measurement (APHA, 1980) } \\
\hline Temperature & Visual, thermometer \\
Conductivity & Conductivity meter \\
Salinity & Salinometer \\
$\mathrm{pH}$ & Colorimeteric \\
Total alkalinity & Titrimetric \\
Total hardness & Titrimetric \\
Total suspended solids & Gravimetric \\
Total dissolved solids & Gravimetric \\
Dissolved oxygen & Titrimetric (Winkler) \\
Biological oxygen demand $\left(\mathrm{BOD}_{5}\right)$ & Titrimetric (Winkler) \\
Orthophosphate $\left(\mathrm{PO}_{4}\right)$ & Ascorbic acid \\
Nitrate $\left(\mathrm{NO}_{3}\right)$ & Cadmium reduction \\
Ammonia $(\mathrm{NH} 3)$ & Phenate \\
\hline
\end{tabular}

\section{Fish Sampling}

Fish samples were collected from the experiment fishing and from the fishermen. Two type of fishing gears, electrofishing, and gill net with experiment were used (Nakashizuka \& Stork, 2002). Electrofishing is the single most effective gear for obtaining fish assemblages (Yoder \& Smith, 1999). The specification of the electrofishing used was generator with power source of $2,500 \mathrm{~W}$, amperage output of $4 \mathrm{~A}$, volts $\mathrm{DC}$ output of 500 , and it was equipped with a scoop net. The gear was set up in the motor boat and operated to downstream direction at $0.5 \mathrm{~km}$ length during the daylight. In each sampling station, electrofishing was operated at both side of the river. In each side, the electrofishing was operated two times.

Gill net experiment was carried out in each sampling stations. A sets of gill net with 8 different opening mesh sizes, $0.75,1.0,1.25,1.5,1.75,2.0$, 2.25 , and 2.5 inche was operated at each size of the river of each sampling stations with operation time approximately 4 hours.

In addition to the fishing experiment, fish sample was also collected from the fishermen using different fishing gears such as electrofishing, gill net, and barrier and fence. Fish sample from fishing experiment and from the fishermen were collected, sorted based on their species, labelled, measured for their weight and individual number, and then preserved with $10 \%$ of formaldehyde. Identification of fish species was continued in the laboratory by using Kottelat et al. (1993); Weber \& Beaufort (Vol. 1911-1940).

\section{Data Analysis}

Fish data was tabulated and analyzed further for their diversity and dominance indexs, and relative abundance by using the formula as follows:

\section{Relative abundance:}

$\mathrm{RA}=\frac{n i}{N i}$

where

$\mathrm{RA}=$ relative abundance

ni = individual number of species-i

$\mathrm{Ni}=$ total individual number of species in station-i

Shannon-Wiener Diversity Indexs (Newman, 1994): $s$

$$
\begin{aligned}
& \mathrm{H}^{\prime}=\Sigma \text { pi In pi ............................... (2 } \\
& n=1
\end{aligned}
$$

where:
$H^{\prime}=$ diversity indexs
$\mathrm{S}=$ total species number
$\mathrm{pi}=\mathrm{ni} / \mathrm{Ni}$
$\mathrm{ni}=$ individual number of species-i
$\mathrm{Ni}=$ total individual number of species in station-i 
Diversity indexs can be used to determine the status of aquatic environment degradation (Wilhm \& Dorris, 1968 after Mason, 1981). A value of H' greater than 3 indicated clean water, value in range 1 to 3 were characteristic of moderately polluted condition and values less then 1 characterized heavily polluted conditions.

Simpson Dominance Indexs (Odum, 1971):

$\mathrm{D}=\sum\left(\frac{n i}{N i}\right)^{2}$

where:

$\mathrm{D}=$ Dominance Index

$\mathrm{ni}=$ individual number of species-i

$\mathrm{Ni}=$ total individual number of species in station-i

Water quality parameter and relative abundance of fish were tabulated and analyzed with multivariate analysis. Water quality parameters were analyzed with principal component analysis while relative abundance of the fish calculated with cluster analysis by using statisca version 6 software program. All data were checked for their normal distribution before analyzing with these multivariate analysis. Non normal distribution data were transformed with standard transformation formula as described by Krebs (1989).

\section{RESULTS AND DISCUSSIONS}

\section{Spasial Distribution of Physico Chemical Parameter}

Principal component analysis on correlation matrix of physico chemical parameters of the down stream of Musi River on April and June indicated that the variance at the first, second, and third axis on April was $38.45,17.89$, and $14 \%$ respectively. The total variance of these three principal components was $70.34 \%$, less than that the total variance recorded on June which was $78.02 \%$ (Figure 2 to 4 ). More variance that can be explained on June measurement may relate to the slow water current and water discharge during that time. Eventhough the water volume and water discharge were not measured in this study, it can be indicated by lower water depth and slower water current on June than that on April (Figure 5)

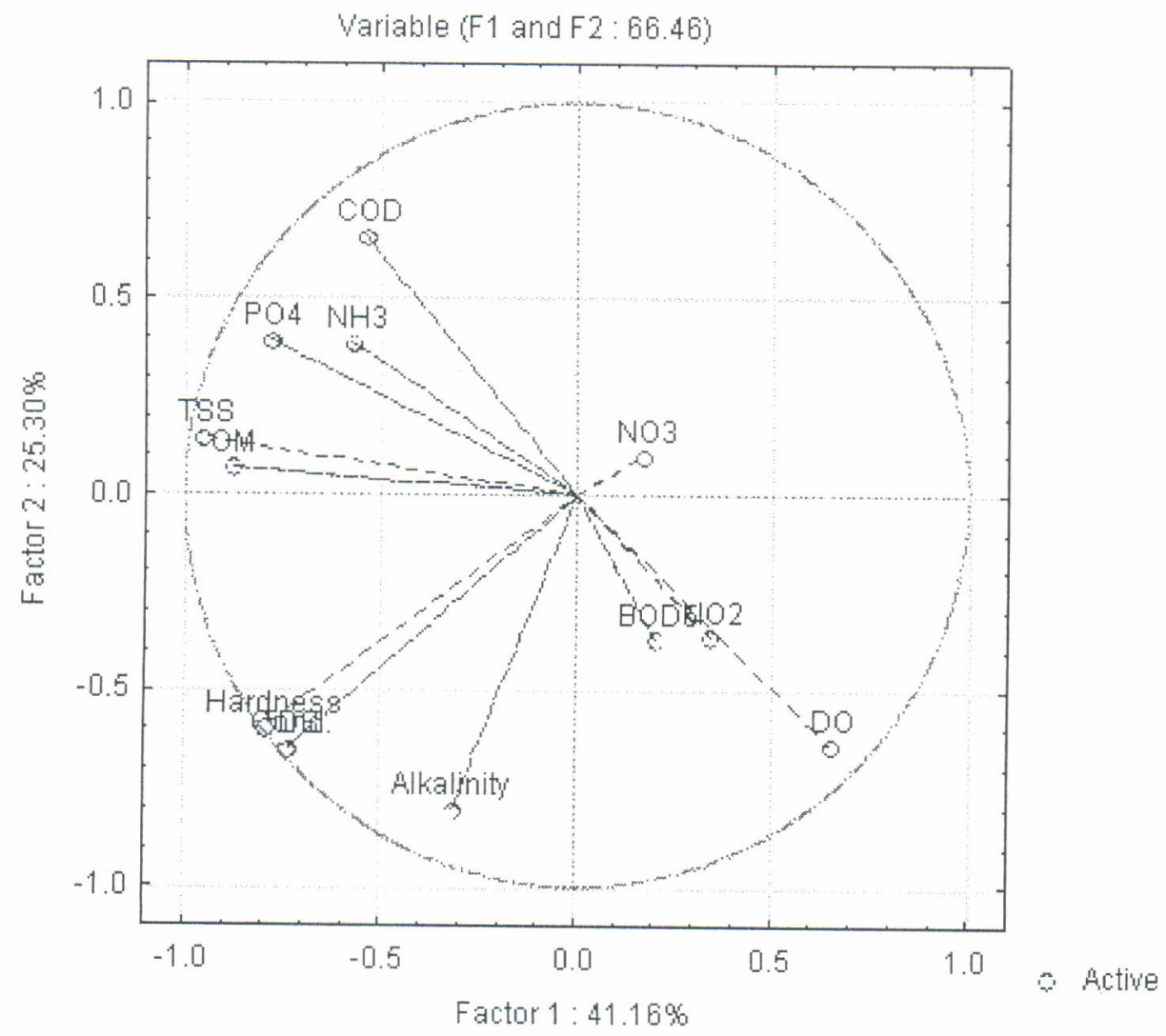

Figure 2. First and second axis of principle component analysis on June. Distribution of physico chemical parameters of the down stream of Musi River 


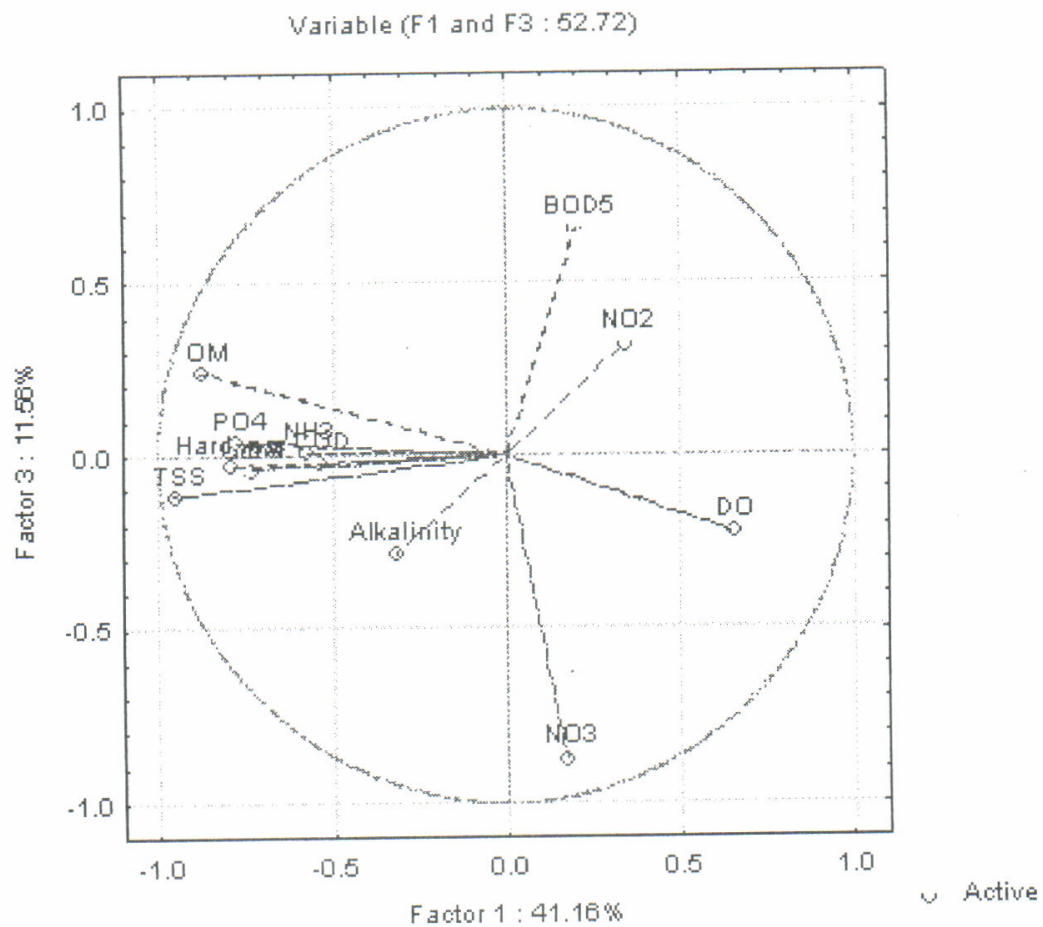

Figure 3a. First and third axis of principle component analysis on June. Distribution of physico chemical parameters of the down stream of Musi River.

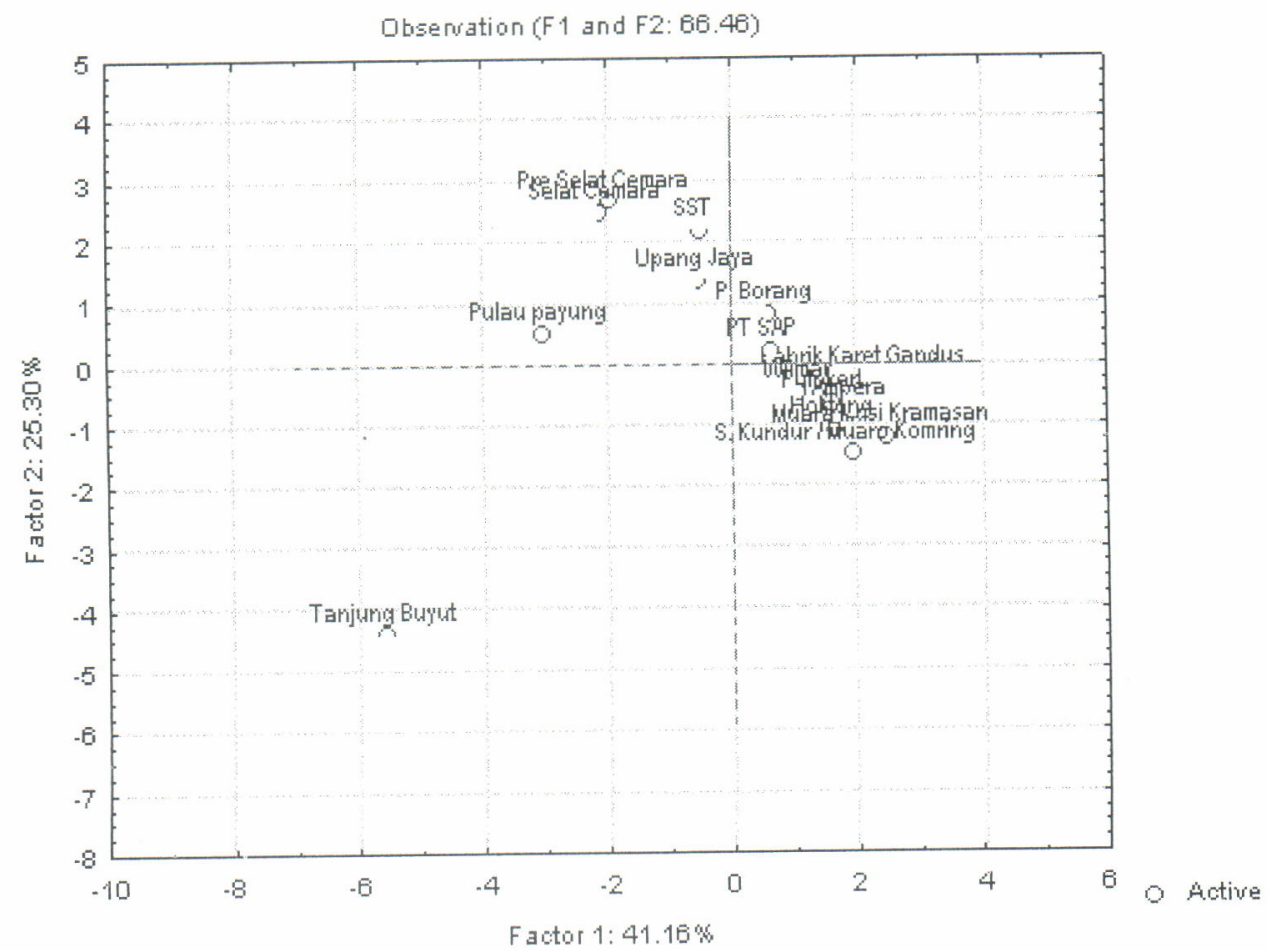

Figure 3b. First and second axis of principle component analysis on June. Distribution of stations of the down stream of Musi River. 


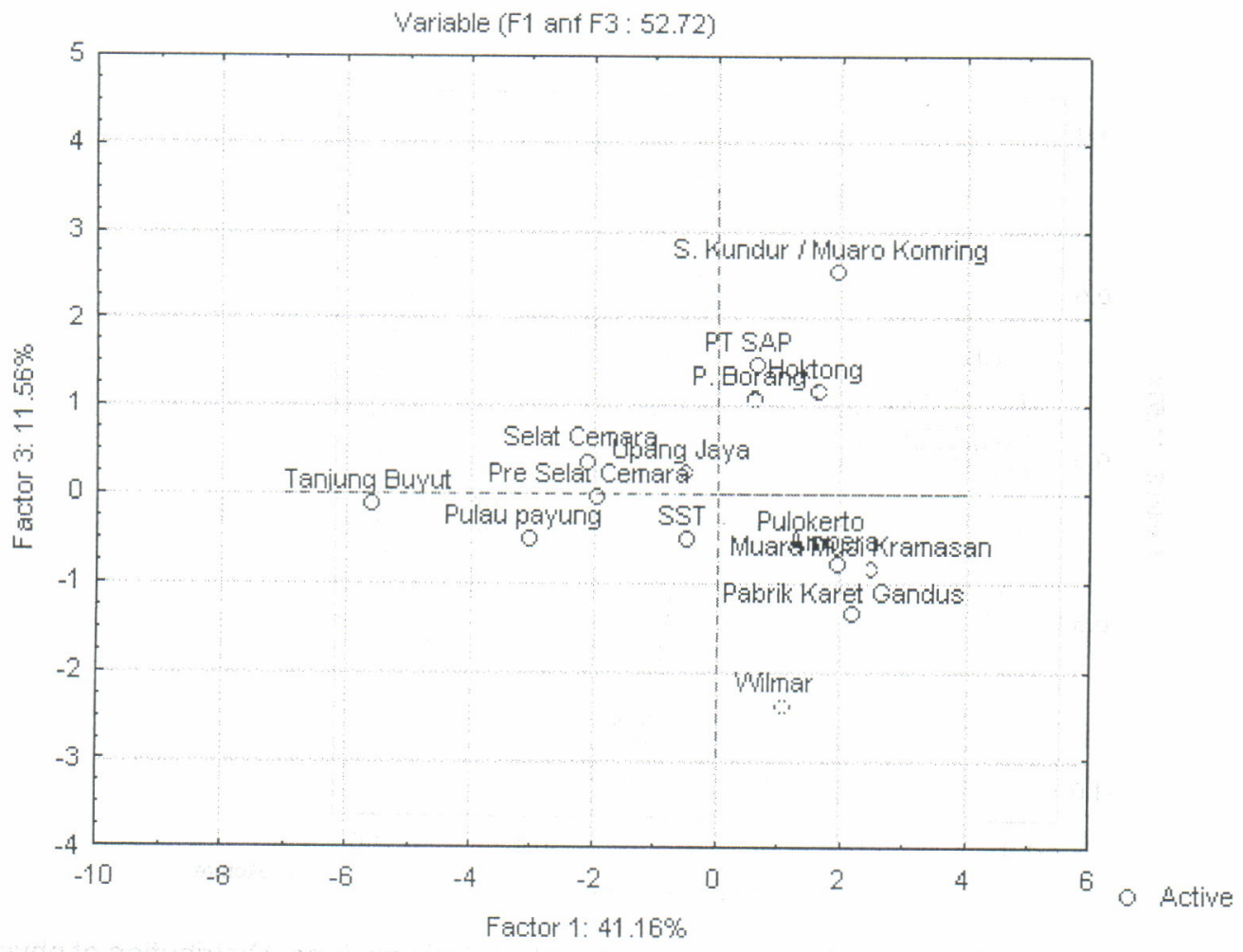

Figure 4. First and third axis of principle component analysis on June. Distribution of stations of the down stream of Musi River.
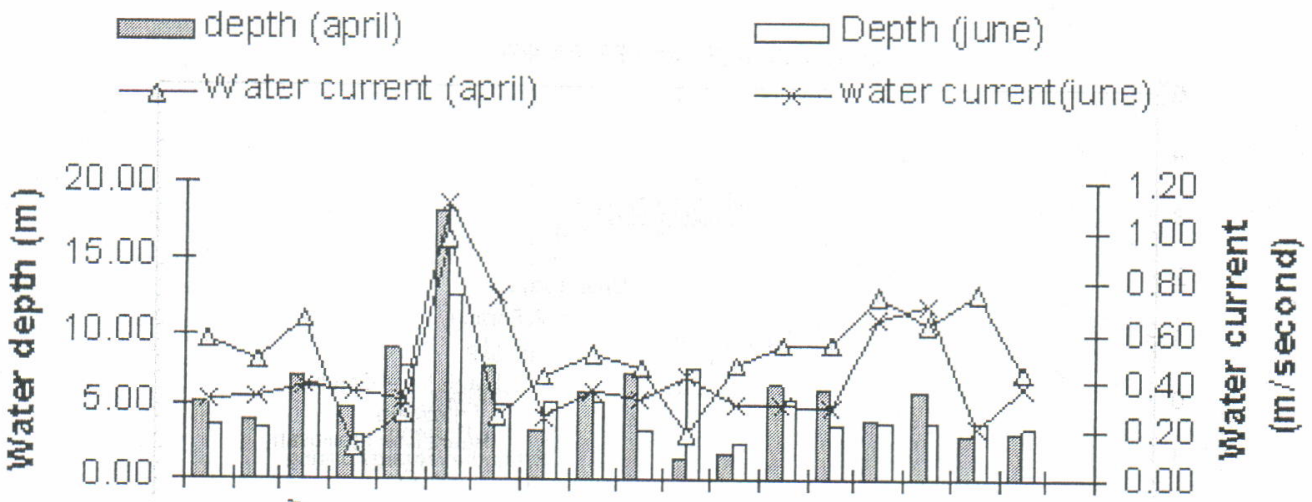

$\square$ Depth (june)

$\rightarrow$ water current(june)

Figure 5.

Sampling station

Principal component analysis showed that there were six groups of station both on April and June observations. The first group were consisted of station Pulokerto, Gandus, and Muara Musi Kramasan. The second group was Musi II, Muara Ogan, and Wilmar. The third group were Pusri, Hoktong, and Kundur River. The forth were PT. SAP, Borang, total suspended solids, and the fifth groups were Upang, Pre Cemara,
Selat Cemara, and Pulau Payung. The last group was Teluk Buyut.

In April, the first group was characterized by low concentration of total dissolved solids, organic matter and nitrate, while on June it was characterized by low concentration of hardness and phosphate. The second group was characterized by low concentration of total 
dissolved solids and organic matter but high concentration of hardness and nitrate. In June, it was similar except for extreme high conductivity and total dissolved solids, while in April, the third group was characterized by low hardness and high in ammonia, while in June, the water quality was in moderate concentration. In April the fourth group was characterized by low in total suspended solids and total dissolved solids, while in June it was characterized by high in ammonia. The fifth and the six group had characteristic almost similar with high concentration of all water quality parameters, except for low ammonia content of group six in April.

The first station group was located at the upper part of other station. Most of activity in this area was rice field with some of two rubber factory and one soya ketchup industry. A better water quality in this stations than that other stations was indicated by low to moderate concentration of physico chemical water parameter. The second station group, which is closed by to the first group, the extreme increasing in conductivity and total dissolved solids concentration in June might relate to sand mining activity located to Musi II stations. As already mention earlier that low water depth and slow water current was suitable for sand mining activities. In the third group, high concentration of ammonia on April could relate to the presence of in organic fertilizer industry. High concentration of most of water quality parameters in fifth and six group was mostly influence by the natural phenomenon since this two group closed by to the mouth of the Musi River.

\section{Fish Community Structure in Relation to the Aquatic Environmental}

The total number of fish species found at the down stream of Musi River in April and June was 112 species. In April the number species recorded was 55 species or $49.11 \%$ of total species found, while in June it was 105 species or $93.75 \%$ of the total species. High percentage of fish species found in June might relate to shallower water depth and slower water current than that in April. This condition make the chance of fish was captured by most of fishing gears. According to Hughes \& Oberdoff (1998); Welcomme (2001), fishing activity in large river mostly affected by the water depth. Electrofishing was more effective operated in shallow water than that in deep water.

Analysis of diversity index revealed that in April, the diversity index in all station were less than 1 while on June it was in the range of 1 to 2 in most of stations, except at station Pusri and Teluk Buyut. Low diversity index on April could relate to the effectiveness of the fishing gear due to high water depth and water current. The diversity index in the range 1 to 2 showed that aquatic environment was in the degradation process. According To Whilm \& Dorris (1968) after Mason (1981), the environment was in degradation process if the diversity index in the range of 1 to 3 .

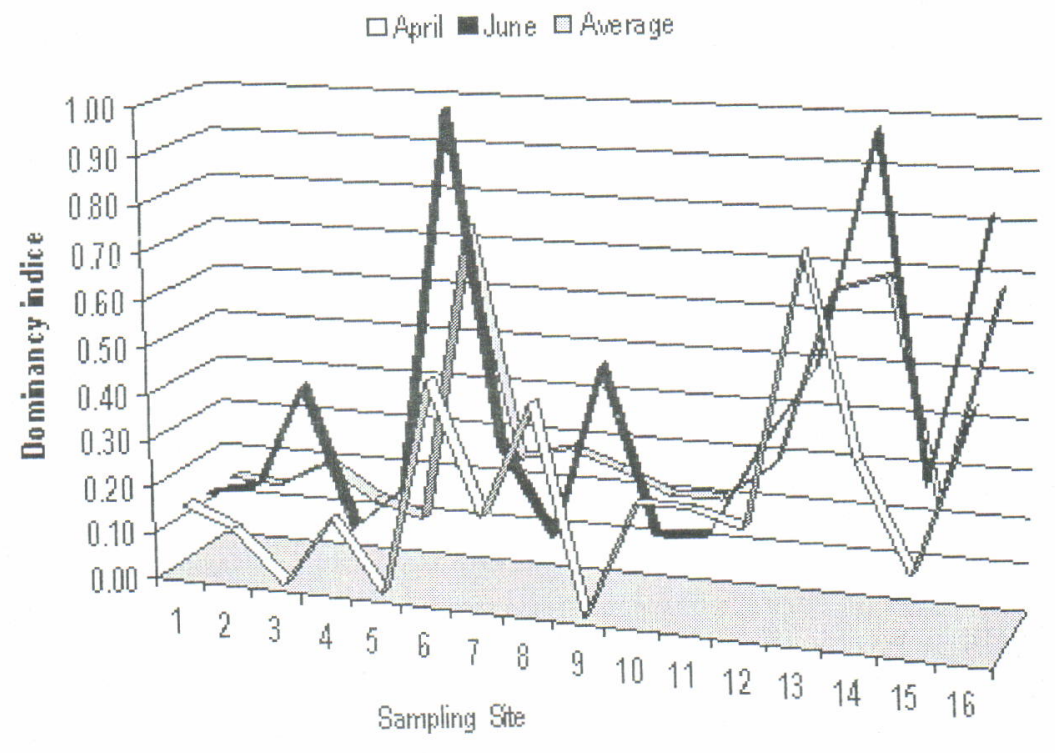

Figure 6. Dominance index of fish at the down stream of Musi River. 
This finding was quite similar with study conducted by Husnah et al. (2007) that used macrozoobenthos as an indicator of aquatic degradation. The diversity index was in the range 1 to 2 . The lowest diversity index was occurred in station Pusri and Selat Cemara.

A more clear picture on the condition of fish community structure can be extrated from dominance index (Figure 6). High Simpson Index at station Pusri and Selat Cemara supported the statement earlier on the low diversity index in both stations. Even though both Pusri and Selat Cemara Stations having low diversity index and high dominance index, the dominant fish species in Pusri was different from the dominant species in Selat Cemara. In Pusri station, fish community was dominated by small sized fish such as (Rasbora sp.) with relative abundance reached $60.61 \%$ while in Selat Cemara it was dominated by larged sized fish such as Lycothrissa crocodiles that it relative abundance reached 100\% (Appendix 2). This phenomenon in accordance with Welcomme (2001) statement that decreasing quality of aquatic environment can be indicated by reducing fish size and domination of small sized Cyprinid fish.
Small number of fish being caught in April influenced the cluster analysis on relative abundance in relation to the aquatic environment (Appendix 1). Due to this fact, the result discussion presented in this considered more to June observation (Appendix 2). Station group resulted from this cluster analysis was quite different from the station group based on physico chemical parameter (Figure 7). Two station groups was found. The first station group was Pulokerto, Gandus, Muara Musi Kramasan, PT. SAP, Pusri, and Hoktong, and the second station group was the rest of all stations. The first group characterized by low concentration of phyco chemical water quality parameter but high in nitrite concentration, while the second station group characteristic was high concentration of all water quality parameters except nitrite. The first station group was dominated by small sized fish such as Barbodes schwanenfeldii, Clupeoides borneensis, Crossochilus oblongus, Rasbora argyrotaenia var 1 , while the second group dominated by Boesemania microlepis, Cyclocheilichtys enoplos, Mystus gulio, and Mystus wolfii. Boesemania microlepis and Cyclocheilichtys enoplos were mid layer and economic fish with their average size longer than the fish species in group station 1.

Euclidean distances

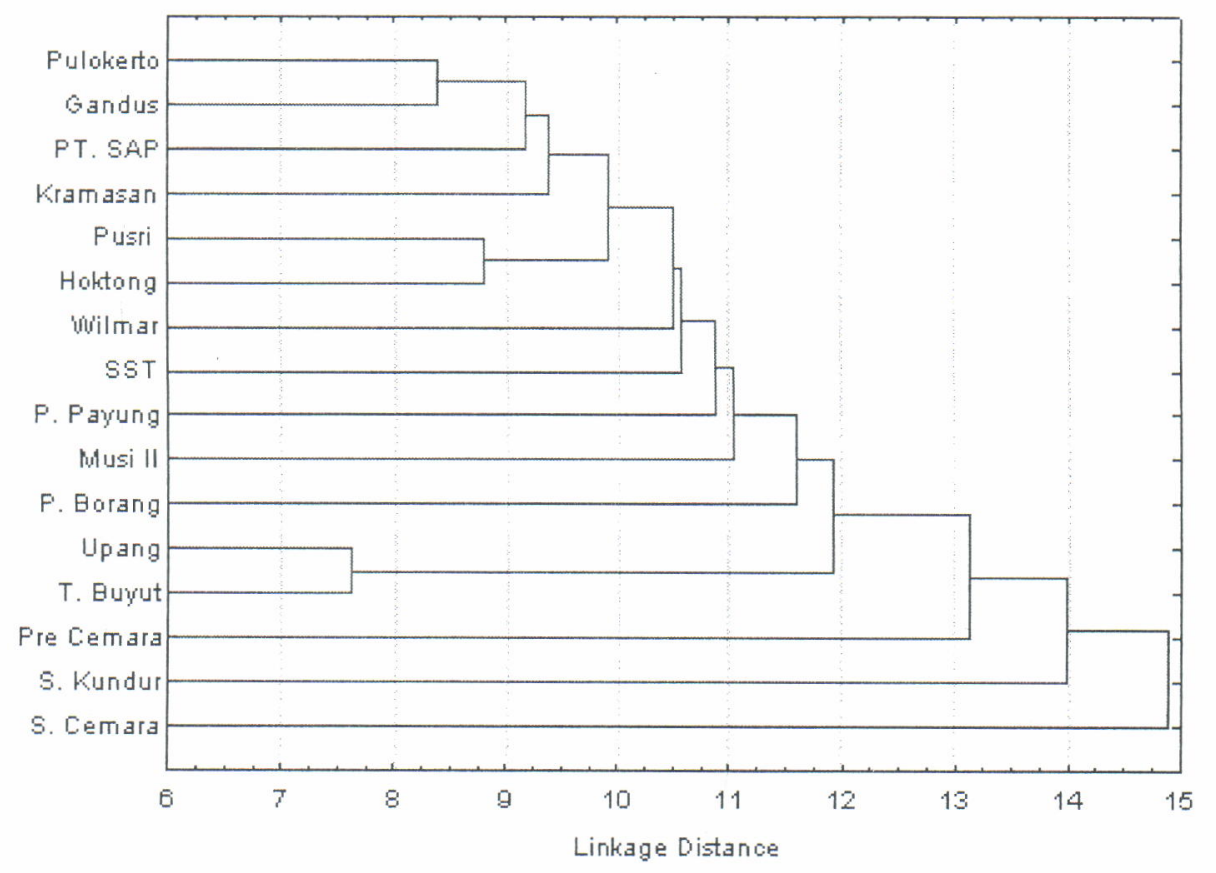

Figure 7. Cluster analysis of fish relative abundance based on station.

It can be summarized that fish community structure through simple diversity and dominance index, and proportionate abundance of species (relative abundance) can be used to determine the quality of aquatic environment. The down stream of
Musi River station Gandus to PT. SAP was in degradation process state indicated by diversity index in the range of 1 to 2 and high proportion of small fish than that the large fish. 


\section{CONCLUSSIONS AND RECOMENDATIONS}

Fish community structure through simple diversity and dominance index, and proportionate abundance of species (relative abundance) can be used to determine the quality of aquatic environment. The down stream of Musi River starting from station Gandus to PT. SAP was in degradation process indicated by diversity index in the range of 1 to 2 and high proportion of small fish than that the large fish. It recommend to find the alternative way to reduced total dissolved solids resulted from sand mining in Musi II station, and ammonia and nitrite concentration of Pusri and Hoktong stations.

\section{REFERENCES}

APHA. 1980. Standard method for the examination of water and wastewater. Fifth Edition. Washington. $1134 \mathrm{p}$

Badan Pengendalian Dampak Lingkungan. 1997. Program kali bersih (prokasih) Sungai Musi. Laporan Tahunan. Pemerintah Propinsi Daerah Tingkat I. Sumatera Selatan. Palembang. 98 hal.

DeYoe, H. R. 2001. River plankton and water quality of the lower Rio Grande/Rio Bravo, texas, USA. Journal of Phycology. 37. 3. p. 16-17.

Ganasan, V. \& R. M. Hughes. 1998. Application of an index of biological integrity to fish assembalges of the River Khan and Kshipra (Madhya Pradesh), India. Freshwater Biology. 40. 367-383.

Hughes, R. M. \& T. Oberdoff. 1998. Application of index of biological integrity concepts and metrics to wter outside the united States and Canada. In Assessing the Sustainability and Biological Integrity of Water Resources Using Fish Communities. T. P. Simon (ed). C. R. C. Press. Washington D. C. p. 79-93.

Husnah, E. Prianto, S. N. Aida, D. Wijaya, A. Said, Sulistiono, S. Gautama, \& Makri. 2007. Inventarisasi jenis dan sumber bahan polutan serta parameter biologi untuk metode penentuan tingkat degradasi lingkungan di Sungai Musi. Laporan Tahunan. Balai Riset Perikanan Perairan Umum. Pusat Riset Perikanan Tangkap. Palembang.

Kreb, C.J. 1989. Ecological methodology. Harper and Row. Publisher. New York. 654
Kottelat, M., A. J. Whitten, S. N. Kartikasari, \& S Wirjoatmojo. 1993. Freshwater fishes of western Indonesia and Sulawesi. Periplus Editions Limited. Jakarta. $221 \mathrm{p}$.

Le Land, H. V. \& S. V. Fend. 1998. Benthic invertebrate distributions in the San Joaquin River, California, in relation to physical and chemical factor. Canadian Journal of Fisheries and Aquatic Sciences. May 1998. 55. 5. Academic Research Library. p. 1,051-1,067.

Mason, C. F. 1981. Biology of freshwater pollution. Longman Inc. New York. 240 p.

Nakashizuka, T. \& N. Stork. 2002. Biodiversity research methods. Kyoto University Press. Kyoidai Kaikan. 216 p.

Newman, M. C. 1994. Quantitative methods in aquatic toxicology. Lewis Publishers. Unites State of America. 426.

Odum, E. P. 1971. Fundamental of ecology. $3^{\text {rd }}$ Edition. W. B. Sounders Company. Philadelphia.

Schiemer, F. 2000. Fish as indicator for the assessment of the ecological integrity of large river. Hydrobiologia. 422/423. 271-278.

Simon, T. P. 1998. Introduction: Biological integrity and use of ecological health concepts for application to water resource characterization. In Assessing the sustainability and biological integrity of water resources using fish communities. T. P. Simon (ed). C. R. C. Press. Washington D. C. p. 3-15.

Smogor, R. A. \& P. L. Angenmeier. 1998. Effect of drainage basin and anthropogenic disturbance on relaation between stream size and index of biological integrity metric in Virginia. In Assesing the Sustainability and Biological Integrity of Water Resources Using Fish Communities. Simon, T. P. (ed) C. R. C. Press L. L. C. Washington D. C. p. 249-272.

Soto-Galera, E., E. Diaz-Pardo, E. Lopez-Lopez, \& J. Lyons. 1998. Fish as indicators of envieonmental quality in the Rio Lerma Basin, Mexico. Aquatic Ecosystem Health and Management. 1. 267-276. 
Weber, M. \& L. F. de Beufort. 1911. The fishes of Indo-Australian Archipelago I. Index to Ichthyological Papers of P. Bleeker. Brill. Leiden.

Weber, M. \& L. F. de Beufort. 1913. The fishes of Indo-Australian Archipelago II. Malacopterygii, MYctophoidea, Ostariophysi I. Siluroidea. Brill. Leiden.

Weber, M. \& L. F. de Beufort. 1916. The fishes of Indo-Australian Archipelago III. Ostariophysi II. Cyprinoidea, Apodes, Synbranchii. Brill. Leiden.

Weber, M. \& L. F. de Beufort. 1922. The fishes of Indo-Australian Archipelago IV Heteronomi, Solenichthyes, Synentognathi, Percesoces, Labyrinthici, Mycrocyprini. Brill. Leiden.

Weber, M. \& L. F. de Beufort. 1929. The fishes of Indo-Australian Archipelago. $V$ Anacanthini, allotriognathi, Heterosomata, Berycomorphi, Percomorphi. Brill. Leiden.

Weber, M. \& L. F. de Beufort. 1931. The fishes of Indo-Australian Archipelago VI Perciformes (continued). Brill. Leiden.

Weber, M \& L. F. de Beufort. 1936. The fishes of IndoAustralian Archipelago VII Perciformes (continued). Brill. Leiden.
Weber, M. \& L. F. de Beufort. 1940. The fishes of Indo-Australian Archipelago VII Percomorphi (continued). Brill. Leiden.

Welcomme, R. L. 2001. Inland fisheries: Ecology and management. Food and Agriculture Organization of the United State. Blackwell Science. London. $358 \mathrm{p}$.

Yoder, A. \& M. A. Smith. Using fish assemblages in state biological assessment and criteria program: Essential concepts and consideration. In Assessing the sustainability and biological integrity of water resources using fish communities. T. P. Simon (ed). C. R. C. Press. Washington D. C. 1756.

Zivic, I., Markovic Z., \& Brajkovic M. 2004. The change of the qualitative and quantitative composition of macrozoobenthos in the Borkovački brook under the influence of pollution. Proceedings of the $2^{\text {nd }}$ Congress of Ecologists of the Republic of Macedonia with International Participation, 25-29. 10. 2003. Ohrid. Special issues of Macedonian Ecological Society. Vol.6.Skopje. 
Fish Community Structure in Relation ..... Musi River, South Sumatera, Indonesia (Husnah et al.)

Appendix 1. Relative abundance of some fish at the down stream of Musi River on April 2007

\begin{tabular}{|c|c|c|c|c|c|c|c|c|c|c|c|c|c|c|c|}
\hline \multirow{2}{*}{ Fish species } & \multicolumn{15}{|c|}{ Relative abundance $(\%) /$ Sampling Sktes } \\
\hline & 1 & 2 & 3 & 4 & 6 & 7 & 8 & 10 & 11 & 12 & 13 & 14 & 15 & 16 & 17 \\
\hline $\begin{array}{l}\text { Achiroides } \\
\text { leucorhynchos }\end{array}$ & 0 & 0 & 0 & 1.33 & 0 & 0 & 9.09 & 0 & 0 & 0 & 0 & 0 & 0 & 0 & 0 \\
\hline $\begin{array}{l}\text { Achiroides } \\
\text { melanorhynchus }\end{array}$ & 0 & 0 & 0 & 0 & 0 & 0 & 9.09 & 0 & 0 & 0 & 0 & 0 & 0 & 0 & 0 \\
\hline $\begin{array}{l}\text { Albulichthys } \\
\text { albuloides }\end{array}$ & 0 & 1.52 & 0 & 0 & 0 & 0 & 0 & 0 & 0 & 0 & 0 & 0 & 6.67 & 50 & 0 \\
\hline Barbichthys laevis & 0 & 0 & 16.7 & 0 & 0 & 4.55 & 0 & 6.67 & 0 & 0 & 0 & 0 & 6.67 & 0 & 0 \\
\hline $\begin{array}{l}\text { Barbodes } \\
\text { schwanenfeldii }\end{array}$ & 0 & 0 & 16.7 & 0 & 0 & 0 & 0 & 0 & 0 & 0 & 0 & 0 & 0 & 0 & 8.33 \\
\hline $\begin{array}{l}\text { Boesemania } \\
\text { microlepis }\end{array}$ & 0 & 0 & 33.3 & 2.67 & 2.86 & 4.55 & 0 & 6.67 & 0 & 0 & 0 & 0 & 6.67 & 0 & 0 \\
\hline Bostrichthys sinensis & 6.67 & 0 & 0 & 4 & 2.86 & 0 & 0 & 0 & 0 & 0 & 0 & 0 & 0 & 0 & 0 \\
\hline Chonerhinos remotus & 0 & 1.52 & 16.7 & 0 & 0 & 0 & 0 & 0 & 0 & 0 & 0 & 0 & 0 & 0 & 0 \\
\hline Clarias batrachus & 0 & 0 & 0 & 0 & 0 & 0 & 0 & 0 & 0 & 0 & 0 & 0 & 0 & 0 & 0 \\
\hline Clarias nieuhofii & 0 & 1.52 & 0 & 0 & 0 & 0 & 0 & 0 & 0 & 0 & 0 & 0 & 6.67 & 0 & 0 \\
\hline $\begin{array}{l}\text { Clupeoides } \\
\text { borneensis }\end{array}$ & 0 & 0 & 0 & 0 & 0 & 0 & 0 & 6.67 & 0 & 16.7 & 0 & 0 & 0 & 0 & 0 \\
\hline Coilia borneensis & 0 & 0 & 0 & 0 & 0 & 4.55 & 0 & 0 & 0 & 0 & 0 & 0 & 0 & 0 & 0 \\
\hline $\begin{array}{l}\text { Crossochilus } \\
\text { oblongus }\end{array}$ & 20 & 6.06 & 16.7 & 2.67 & 0 & 0 & 0 & 0 & 0 & 0 & 0 & 0 & 0 & 0 & 0 \\
\hline $\begin{array}{l}\text { Epalzeorhynchus } \\
\text { kallopterus }\end{array}$ & 0 & 3.03 & 0 & 2.67 & 0 & 0 & 0 & 0 & 0 & 0 & 0 & 0 & 0 & 0 & 0 \\
\hline Escualosa thoracata & 0 & 6.06 & 0 & 0 & 2.86 & 9.09 & 9.09 & 0 & 0 & 0 & 0 & 0 & 6.67 & 50 & 0 \\
\hline Glossogobius giuris & 0 & 0 & 0 & 0 & 0 & 0 & 0 & 0 & 0 & 0 & 0 & 0 & 0 & 0 & 0 \\
\hline $\begin{array}{l}\text { Glossogobius giuris } \\
\text { spp2. }\end{array}$ & 0 & 1.52 & 0 & 0 & 0 & 0 & 0 & 6.67 & 0 & 0 & 0 & 0 & 0 & 0 & 0 \\
\hline $\begin{array}{l}\text { Hampala } \\
\text { macrolepidota }\end{array}$ & 0 & 0 & 0 & 1.33 & 0 & 0 & 0 & 0 & 0 & 0 & 0 & 0 & 0 & 0 & 8.33 \\
\hline $\begin{array}{l}\text { Hemisilurus } \\
\text { scleronema }\end{array}$ & 0 & 0 & 0 & 0 & 0 & 0 & 0 & 0 & 0 & 0 & 0 & 0 & 0 & 0 & 8.33 \\
\hline Kryptopterus sp. & 0 & 6.06 & 0 & 0 & 0 & 0 & 0 & 0 & 0 & 0 & 0 & 0 & 0 & 0 & 0 \\
\hline Kryptopterus apogon & 0 & 0 & 0 & 0 & 0 & 0 & 0 & 0 & 12.5 & 0 & 0 & 0 & 0 & 0 & 0 \\
\hline $\begin{array}{l}\text { Kryptopterus } \\
\text { micronema }\end{array}$ & 0 & 0 & 0 & 2.67 & 0 & 0 & 0 & 0 & 0 & 0 & 0 & 0 & 0 & 0 & 0 \\
\hline Kryptopterus minor & 6.67 & 3.03 & 0 & 24 & 17.1 & 13.6 & 63.6 & 0 & 0 & 0 & 0 & 0 & 6.67 & 0 & 0 \\
\hline $\begin{array}{l}\text { Labeo } \\
\text { chrysophekadion } \\
\text { Labeobarbus }\end{array}$ & 0 & 18.2 & 0 & 2.67 & 0 & 4.55 & 0 & 0 & 0 & 0 & 0 & 0 & 0 & 0 & 0 \\
\hline $\begin{array}{l}\text { Labeobarbus } \\
\text { cuvieri/Labeobarbus } \\
\text { leptocheilus }\end{array}$ & 0 & 3.03 & 0 & 0 & 0 & 0 & 0 & 0 & 0 & 0 & 0 & 0 & 0 & 0 & 0 \\
\hline Labeo erythropterus & 20 & 1.52 & 0 & 0 & 0 & 0 & 9.09 & 0 & 0 & 0 & 0 & 0 & 0 & 0 & 0 \\
\hline Labiobarbus ocellatus & 0 & 0 & 0 & 1.33 & 0 & 0 & 0 & 0 & 0 & 0 & 0 & 0 & 0 & 0 & 0 \\
\hline Laides hexanema & 0 & 0 & 0 & 0 & 0 & 0 & 0 & 0 & 0 & 0 & 0 & 0 & 0 & 0 & 16.7 \\
\hline $\begin{array}{l}\text { Leiocassis } \\
\text { mahakamensis }\end{array}$ & 0 & 0 & 0 & 0 & 0 & 0 & 0 & 0 & 0 & 0 & 0 & 25 & 6.67 & 0 & 8.33 \\
\hline $\begin{array}{l}\text { Leptosynanceia } \\
\text { asteroblepa }\end{array}$ & 0 & 0 & 0 & 0 & 0 & 0 & 0 & 0 & 0 & 0 & 0 & 0 & 0 & 0 & 8.33 \\
\hline Liza tade & 0 & 0 & 0 & 0 & 0 & 0 & 0 & 6.67 & 25 & 16.7 & 0 & 0 & 6.67 & 0 & 0 \\
\hline $\begin{array}{l}\text { Lycothrissa } \\
\text { crocodilus }\end{array}$ & 0 & 0 & 0 & 0 & 2.86 & 0 & 0 & 0 & 0 & 0 & 12.5 & 50 & 6.67 & 0 & 0 \\
\hline $\begin{array}{l}\text { Mastacembelus } \\
\text { erythrotaenia }\end{array}$ & 0 & 3.03 & 0 & 0 & 0 & 0 & 0 & 0 & 0 & 0 & 0 & 0 & 0 & 0 & 0 \\
\hline Microphis brachyurus & 0 & 0 & 0 & 0 & 0 & 0 & 0 & 0 & 0 & 0 & 0 & 0 & 0 & 0 & 16.7 \\
\hline Muraenesox talabon & 0 & 0 & 0 & 0 & 0 & 0 & 0 & 0 & 0 & 0 & 87.5 & 0 & 0 & 0 & 0 \\
\hline Mystus gulio & 0 & 0 & 0 & 0 & 0 & 4.55 & 0 & 6.67 & 0 & 0 & 0 & 0 & 0 & 0 & 0 \\
\hline Mystus nemurus & 0 & 0 & 0 & 0 & 0 & 0 & 0 & 46.7 & 0 & 0 & 0 & 0 & 0 & 0 & 0 \\
\hline Ompok bimaculatus & 0 & 1.52 & 0 & 1.33 & 0 & 0 & 0 & 0 & 0 & 0 & 0 & 0 & 0 & 0 & 0 \\
\hline $\begin{array}{l}\text { Ophiocephalus } \\
\text { striata/Channa striata }\end{array}$ & 0 & 0 & 0 & 1.33 & 0 & 0 & 0 & 0 & 0 & 0 & 0 & 0 & 0 & 0 & 0 \\
\hline
\end{tabular}


Continuing Appendix 1. Relative abundance of some fish at the down stream of Musi River on April 2007

\begin{tabular}{|c|c|c|c|c|c|c|c|c|c|c|c|c|c|c|c|}
\hline \multirow{2}{*}{ Fish species } & \multicolumn{15}{|c|}{ Relative abundance (\%)/Sampling Sktes } \\
\hline & 1 & 2 & 3 & 4 & 6 & 7 & 8 & 10 & 11 & 12 & 13 & 14 & 15 & 16 & 17 \\
\hline Oreochromis niloticus & 0 & 0 & 0 & 4 & 0 & 0 & 0 & 0 & 0 & 0 & 0 & 0 & 0 & 0 & 0 \\
\hline Osteochilus hasseltii & 20 & 22.7 & 0 & 0 & 0 & 22.7 & 0 & 0 & 0 & 0 & 0 & 0 & 0 & 0 & 0 \\
\hline $\begin{array}{l}\text { Osteochilus } \\
\text { melanopleura }\end{array}$ & 0 & 3.03 & 0 & 6.67 & 0 & 0 & 0 & 0 & 0 & 0 & 0 & 0 & 0 & 0 & 0 \\
\hline Osteochilus schlegelli & 0 & 3.03 & 0 & 0 & 2.86 & 0 & 0 & 0 & 0 & 0 & 0 & 0 & 0 & 0 & 8.33 \\
\hline $\begin{array}{l}\text { Osteochilus vittatus/0. } \\
\text { microcephalus }\end{array}$ & 0 & 0 & 0 & 0 & 0 & 0 & 0 & 0 & 0 & 0 & 0 & 0 & 0 & 0 & 0 \\
\hline Otolithoides pama & 0 & 0 & 0 & 1.33 & 0 & 0 & 0 & 0 & 0 & 0 & 0 & 0 & 0 & 0 & 0 \\
\hline $\begin{array}{l}\text { Pangasius } \\
\text { hypopthalmus }\end{array}$ & 0 & 3.03 & 0 & 0 & 0 & 0 & 0 & 0 & 37.5 & 33.3 & 0 & 25 & 0 & 0 & 8.33 \\
\hline $\begin{array}{l}\text { Pangasius } \\
\text { polyuranodon }\end{array}$ & 0 & 0 & 0 & 0 & 0 & 0 & 0 & 0 & 0 & 0 & 0 & 0 & 0 & 0 & 0 \\
\hline $\begin{array}{l}\text { Parachela } \\
\text { oxygastroides }\end{array}$ & 0 & 0 & 0 & 1.33 & 0 & 0 & 0 & 0 & 0 & 0 & 0 & 0 & 0 & 0 & 0 \\
\hline $\begin{array}{l}\text { Parambassis } \\
\text { macrolepis }\end{array}$ & 0 & 0 & 0 & 0 & 0 & 0 & 0 & 0 & 0 & 16.7 & 0 & 0 & 0 & 0 & 0 \\
\hline $\begin{array}{l}\text { Polynemus } \\
\text { longipectoralis }\end{array}$ & 0 & 0 & 0 & 0 & 0 & 0 & 0 & 0 & 12.5 & 16.7 & 0 & 0 & 0 & 0 & 0 \\
\hline $\begin{array}{l}\text { Polystonemus } \\
\text { multifilis }\end{array}$ & 0 & 1.52 & 0 & 1.33 & 2.86 & 0 & 0 & 0 & 0 & 0 & 0 & 0 & 0 & 0 & 0 \\
\hline Puntius lineatus & 13.3 & 9.09 & 0 & 29.3 & 65.7 & 31.8 & 0 & 0 & 12.5 & 0 & 0 & 0 & 6.67 & 0 & 0 \\
\hline Setipinna taty & 0 & 0 & 0 & 5.33 & 0 & 0 & 0 & 0 & 0 & 0 & 0 & 0 & 0 & 0 & 0 \\
\hline Stolephorus indicus & 0 & 0 & 0 & 0 & 0 & 0 & 0 & 6.67 & 0 & 0 & 0 & 0 & 0 & 0 & 0 \\
\hline Toxotes microlepis & 0 & 0 & 0 & 0 & 0 & 0 & 0 & 0 & 0 & 0 & 0 & 0 & 0 & 0 & 0 \\
\hline Trichiurus sp. & 6.67 & 0 & 0 & 1.33 & 0 & 0 & 0 & 0 & 0 & 0 & 0 & 0 & 0 & 0 & 0 \\
\hline $\begin{array}{l}\text { Trichogaster } \\
\text { pectoralis }\end{array}$ & 6.67 & 0 & 0 & 0 & 0 & 0 & 0 & 0 & 0 & 0 & 0 & 0 & 0 & 0 & 0 \\
\hline $\begin{array}{l}\text { Tricogaster } \\
\text { trichopterus }\end{array}$ & 0 & 0 & 0 & 0 & 0 & 0 & 0 & 0 & 0 & 0 & 0 & 0 & 33.3 & 0 & 8.33 \\
\hline Tylosurus leiurus & 0 & 0 & 0 & 1.33 & 0 & 0 & 0 & 6.67 & 0 & 0 & 0 & 0 & 0 & 0 & 0 \\
\hline $\begin{array}{l}\text { Zenarchopterus } \\
\text { ectuntio }\end{array}$ & 0 & 0 & 0 & 1.33 & 0 & 0 & 0 & 6.67 & 0 & 0 & 0 & 0 & 0 & 0 & 0 \\
\hline
\end{tabular}

Remarks: 1. Pulokerto; 2. Pabrik Karet Gandus; 3. Musi II; 4. Muara Musi Kramasan; 5. Ampera; 6. Wilmar; 7. Pusri; 8. Hoktong; 9. Kundur; 10. PT. SAP; 11. Pulau Borang; 12. Total suspended solids; 13. Upang; 14. Pre Cemara; 15. Selat Cemara; 16. Payung Payung; 17. Teluk Buyut 


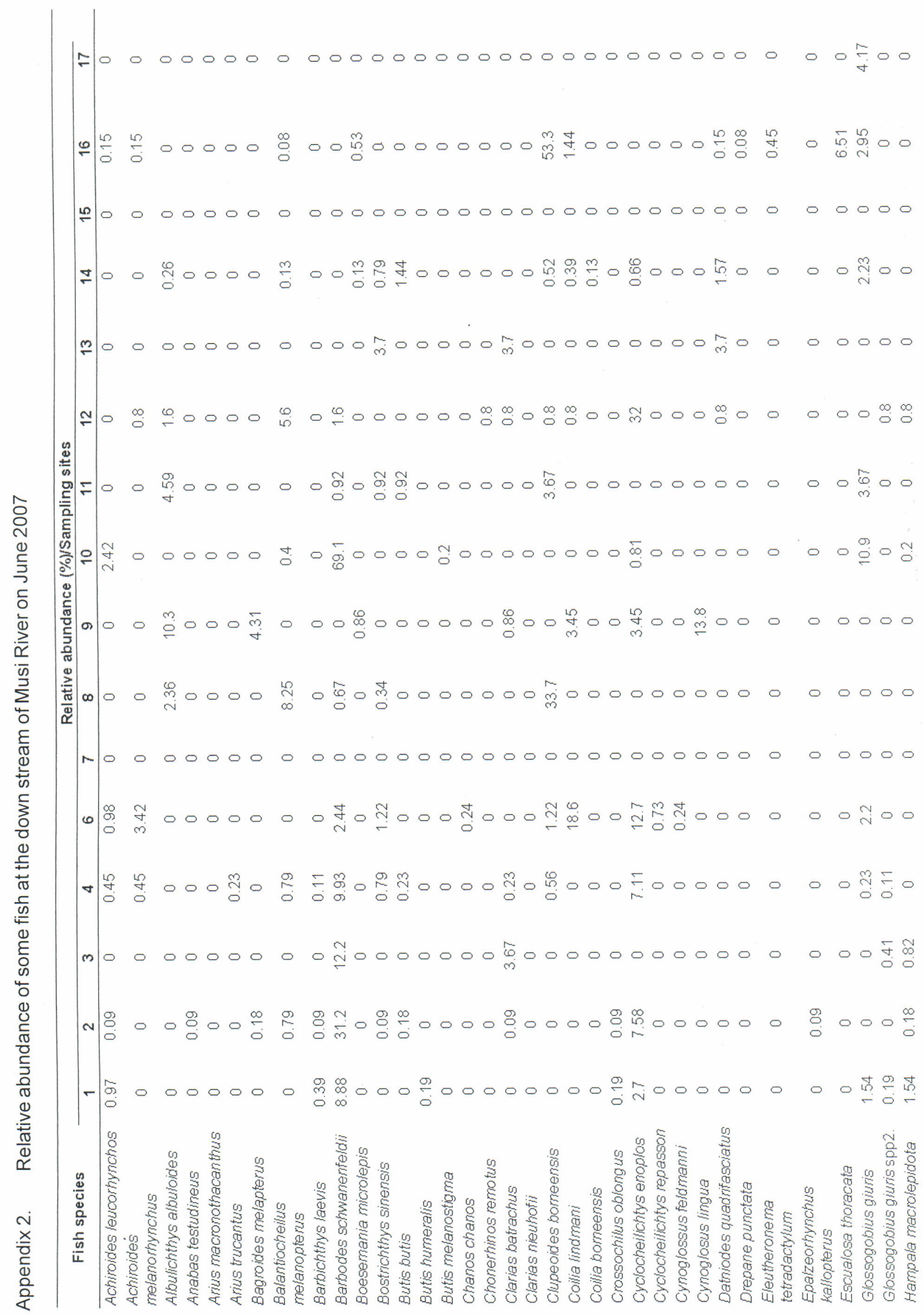




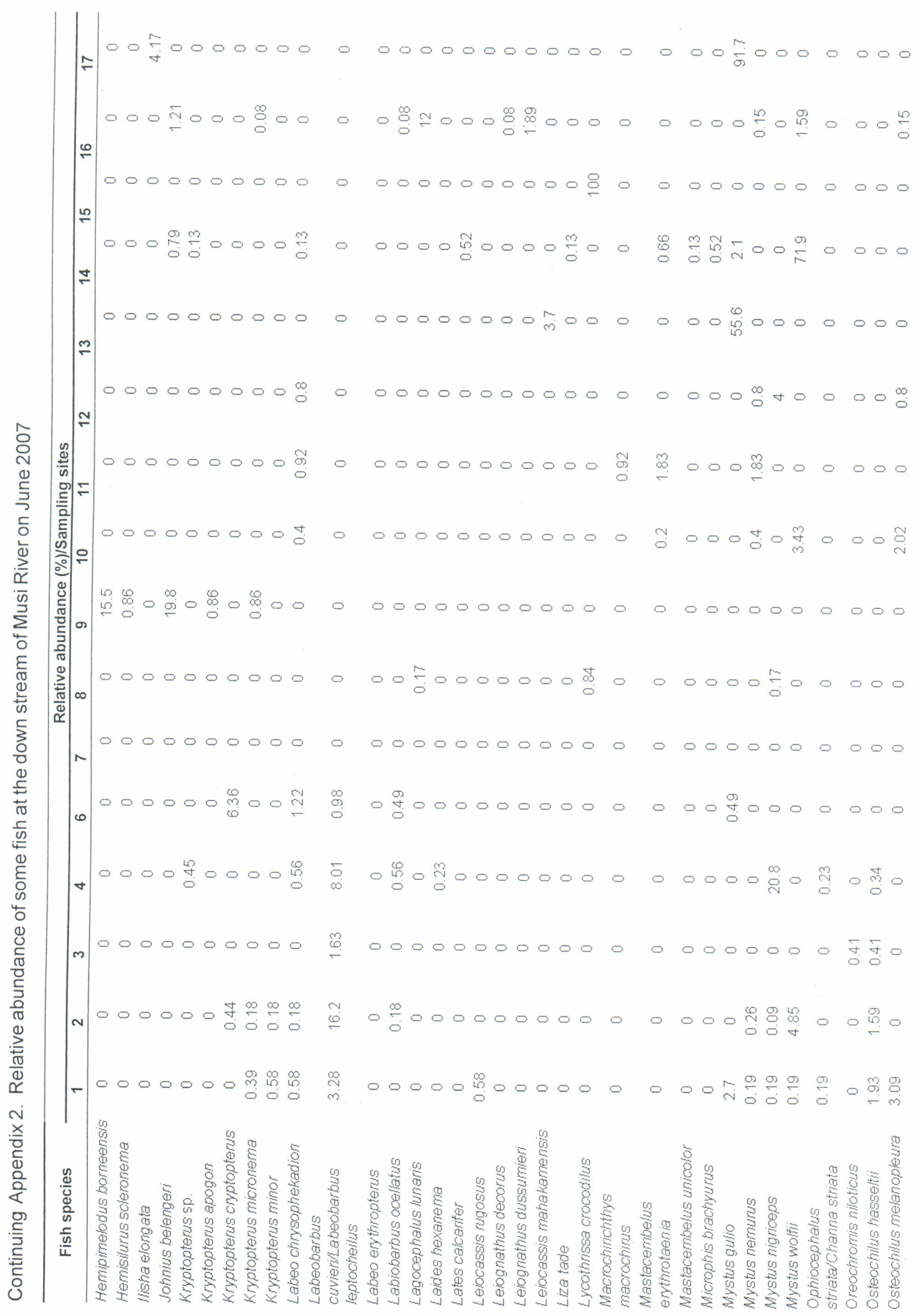


